\title{
Material culture in action: conserving garments deliberately concealed within buildings'
}

\begin{abstract}
Dinah Eastop ${ }^{2}$
RESUMO: $\bigcirc$ estudo da cultura material abrange as propriedades materiais e simbólicas dos objetos. Abordagens do ponto de vista da cultura material podem auxiliar na conservação de têxteis, por encorajar considerações acerca de mudanças de suas propriedades, tanto materiais quanto simbólicas, no decorrer do tempo. Ao analisar os desafios à conservação apresentados por tecidos deliberadamente escondidos em construções, a conservação de têxteis fornece um exemplo do modo de ação da cultura material. A significação atribuída a esses têxteis varia: alguns são valorizados como exemplos raros de vestimentas; outros, por sua função de proteção; e outros, ainda, são vistos como lixo. As estratégias de conservação são indicadas pela significação atribuída a esses têxteis.

PALAVRAS-CHAVE: Cultura Material. Conservação de têxteis. Coleções. Exposição.

ABSTRACT: The study of material culture encompasses the material and the symbolic properties of things. Approaches based on an understanding of material culture can help with the conservation of textiles because they encourage considerations regarding changes in their properties, both material and symbolic, over time. Examples of textile conservation illustrate material culture in action to the extent that they analyze the challenges posed by garments deliberately concealed within buildings to conservation. The significance attributed to such textiles varies: some are valued as rare samples of clothing; others are appreciated for their protective function; while others are viewed as rubbish. The conservation strategies are indicated by the significance attributed to these textiles.

KEYWORDS: Material Culture. Textile Conservation. Collections. Exhibition.
\end{abstract}

1.This paper is based on a presentation I made at the international seminar called Tecidos e sua conservação no Brasil:museus e colleções [Textile Conservation in Brazil:museums and collections] organised by the Museu Paulista of USP, 8-13 May 2006 in São Paulo. It was a great honour to be invited to speak at the seminar and I thank Dr Teresa de Paula for the invitation. I also thank Dr Carvalho, who invited me to contribute this paper to the Annals of the Museu Paulis$t a$. Some of the material reported here was presented at the last biennial congress of the International Institute of Conservation (IIC) in Munich 2006 (EASTOP,2006).

2. Senior Lecturer, and Associate Director of the AHRC Research Centre for Textile Conservation and Textile studies. The Textile Conservation Centre, Winchester School of Art, University of Southampton, Winchester,United Kingdom. E.mail: <dde@soton.ac.uk> The Deliberately Concealed Garments Project has been funded by the L.J. Skaggs and Mary C. Skaggs Foundation and the Arts and Humanities Research Council (UK), and 
forms an important project of theAHRC Research Centre for Textile Conservation and Textile Studies.The exhibition Hidden House History was made possible thanks to the support of Hampshire County Council Museums and Archives Service, the Esmée Fairbairn Foundation and Hampshire County Council. The oral history recording was facilitated by David Lee of the Wessex Sound and Film Archive (UK). I thank Nell Hoare, Director of the Textile Conservation Centre (UK), for permission to publish.
Introduction

This paper argues that an understanding of 'material culture' can help to clarify the practical and ethical dilemmas of curating and conserving textiles. Material culture is concerned with why things matter, by seeking to understand the relationships between persons and things in the past and in the present, in urban and industrialized or in small-scale societies across the globe (TILLEY et al., 2006). The English word 'matter' encompasses two important connotations (EASTOP, 2006i). First, the word 'matter' (as a noun) refers to forms of materiality, as in the three states of matter (solid, liquid and gas). Second, the word 'matter' used as a verb 'to matter' refers to importance or significance. Material culture studies are concerned with integrating both the material and the symbolic aspects of things.

In material culture studies, the focus on the social role of things (e.g. APPADURAI, 1986; EASTOP, 2006a, 2006d) leads to analysis of the materials, technology and circumstances of an object's making (production), its use (usually referred to as 'consumption' in material culture studies) and its disposal. Measures taken to ensure the preservation of an object may be viewed as a stage of production (in the sense of re/presenting an object in a different way, see HANSEN, 2000), consumption (using the object is a new way) or as a form of disposal (if the analyst views museums as places of disposal rather than of production or consumption).

Why things matter and how they come to be attributed significance demands an understanding of how and why significance is attributed by persons to things. Gaining an understanding of this process comes from observation complemented by what people say and write. In order to understand why things matter to people, it is necessary for the significance loften the object's symbolic properties) to be expressed in some form of language, usually written or spoken. This explains the importance attributed to language in this author's analysis of material culture, which can be understood as the interplay between objects (things), subject (persons) and language (usually understood as metaphor) (EASTOP, 1998, 2006c, 2006f) (Figure 1). This paper presents an example from textile conservation

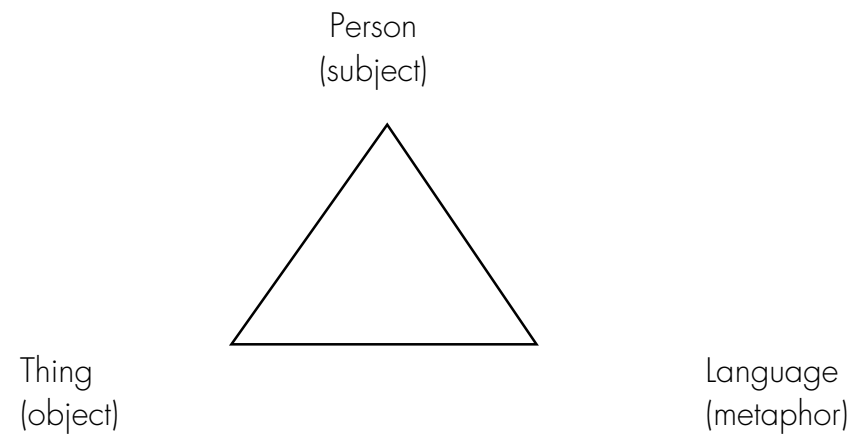

Figure 1 - Diagram representing the author's view of 'material culture' as the interplay between persons, things and language. 
to illustrate material culture in action, via an analysis of the preservation challenges of a special group of textiles: garments that have been deliberately concealed within buildings.

The Deliberately Concealed Garments Project (DCGP)

There is a long-established but seldom reported practice in the UK land elsewhere) of deliberately concealing garments (and other things) within the structure of buildings. Such concealments (which are known as caches from the French word 'to hide') may consist of a single item (e.g. a bottle or shoe) or may consist of several items hidden together. For example, a cache found in a hopfilled wall cavity in a timber-framed house in Abingdon, Oxfordshire, UK, consists of a tie-on pocket dated circa 1740, a child's cap dated 1740-1770, fragments of business documents, as well as trade tokens and coins ranging in date from 1573-1577 and 1797 (Figures 2, 3 and 4). Assemblages of objects of different dates are not uncommon, and this makes it hard to say when the caches were deposited, or whether a particular cache was deposited at one time or was added to over time (EASTON, 1995).

Common sites for concealment include points of entrance (by doorways, window openings, and by chimneys) and in voids (e.g. under floorboards and in blocked-up bread ovens). The practice is also recorded in North Europe, North America, and in Australia (EASTOP; DEW, 2006). The reason (or reasons) for

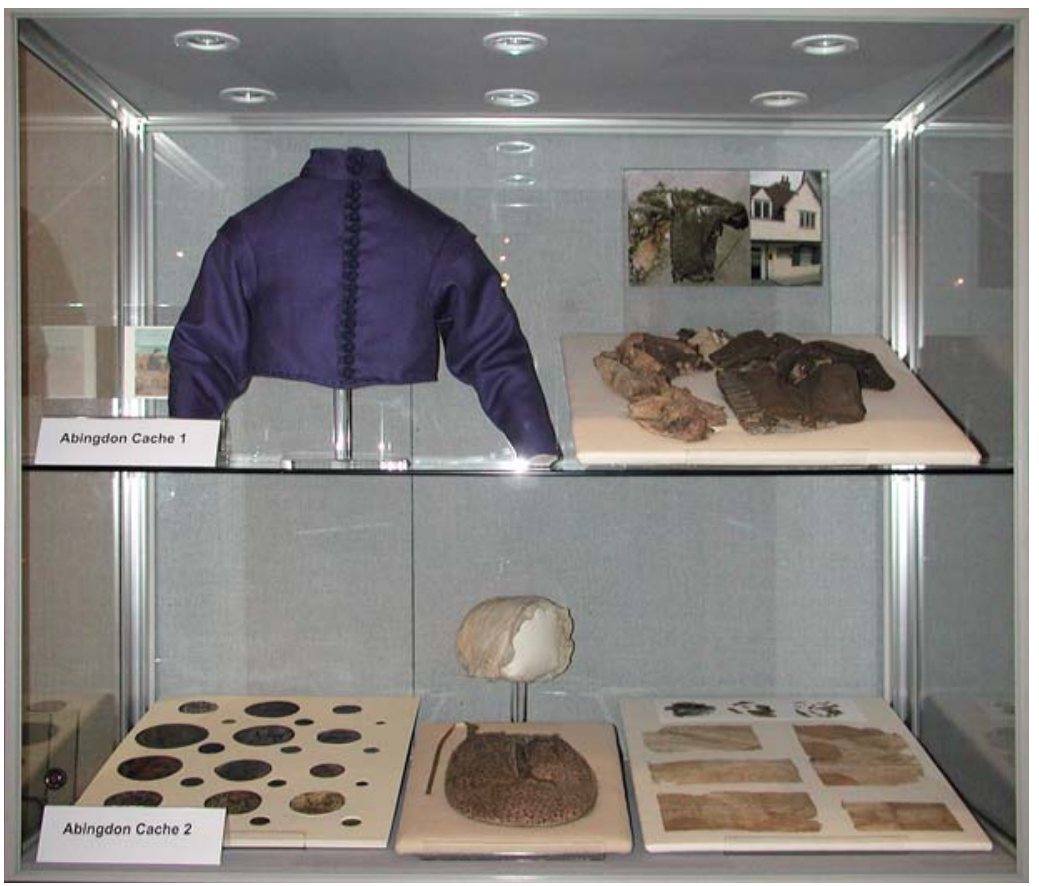

Figure 2 - Display of the two Abingdon Caches in the Hidden House History exhibition. Abingdon Cache 1 consisted of a fragmentary seventeenth century doublet, which was displayed alongside a modern replica doublet. Abingdon Cache 2 consists of an eighteenth century tie-on pocket (centre, front), a child's cap (centre, back), various coins and trade tokens ranging in date form 1573-1577 to 1797 (left), and fragments of business documents (right) (TCC 2304. 1, 2, 3). 

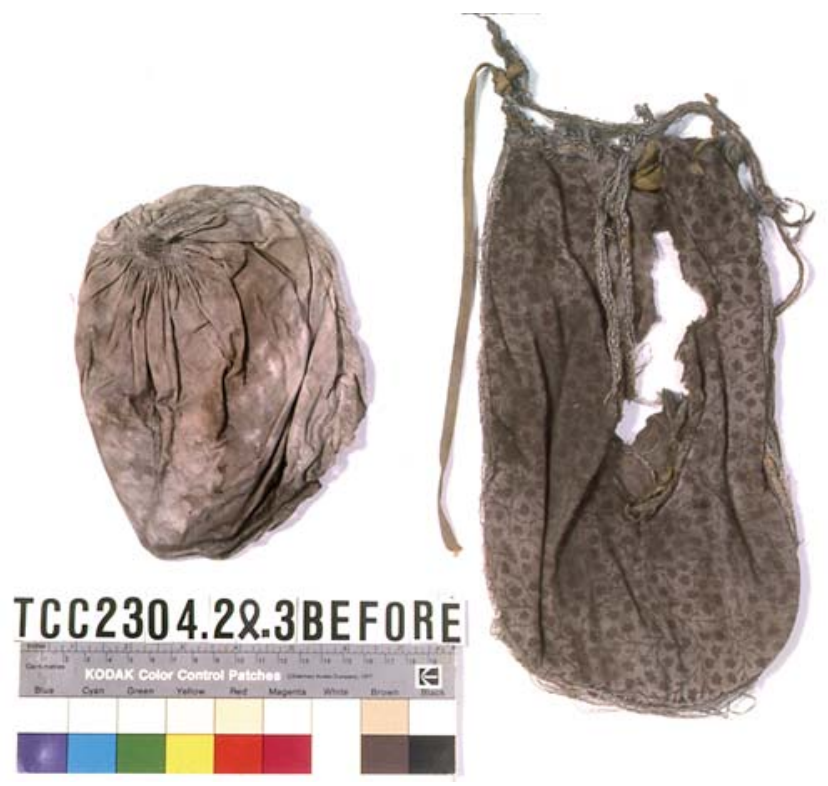

Figure 3 - The pocket and cap from Abingdon Cache 2, before treatment.

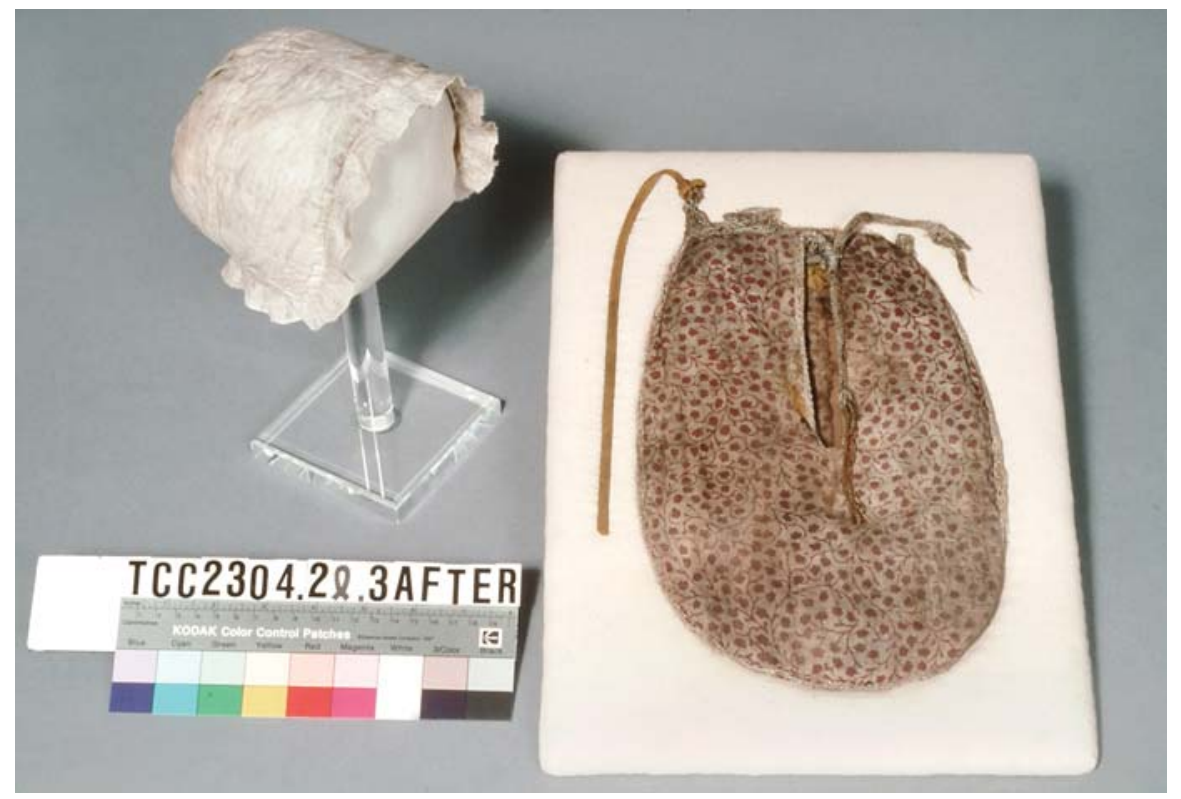

Figure 4 - The pocket from Abingdon Cache 2, after treatment, and prepared for storage. 
concealment is (are) not certain, but some scholars (e.g. MERRIFIELD, 1987) and finders attribute a protective function to the concealment.

In 1998 the author initiated a project, known as the Deliberately Concealed Garments Project ${ }^{3}$, to locate, document and research garments and associated objects found concealed within buildings (EASTOP, 2001 ; EASTOP; DEW; 2003, 2006). The DCGP built on pioneering work undertaken at Northampton Museums and Gardens, where June Swann started an index of boots and shoes found concealed within buildings (SWANN, 1969, 1996). Caches have preserved significant items of historic dress, including $17^{\text {th }}$ century items of everyday dress, such as the linen doublet found in Reigate, Surrey, UK (Figures 5 and 6 ) and a pair of early seventeenth century stays (corset) found in Sittingbourne, Kent, UK (Figure 7).

The aim of the DCGP is to prevent the loss of objects and information about them and about the practice of concealment. The two main objectives are therefore to (i) collect data about the objects and the practice of concealment; and, (ii) to increase the number of finds reported and to reduce the risk of loss or damage to finds by raising public awareness of concealment practices and the significance of the hidden objects.
3.The DCGP is hosted by The Textile Conservation Centre (TCC), Winchester School of Art, University of Southampton, UK.

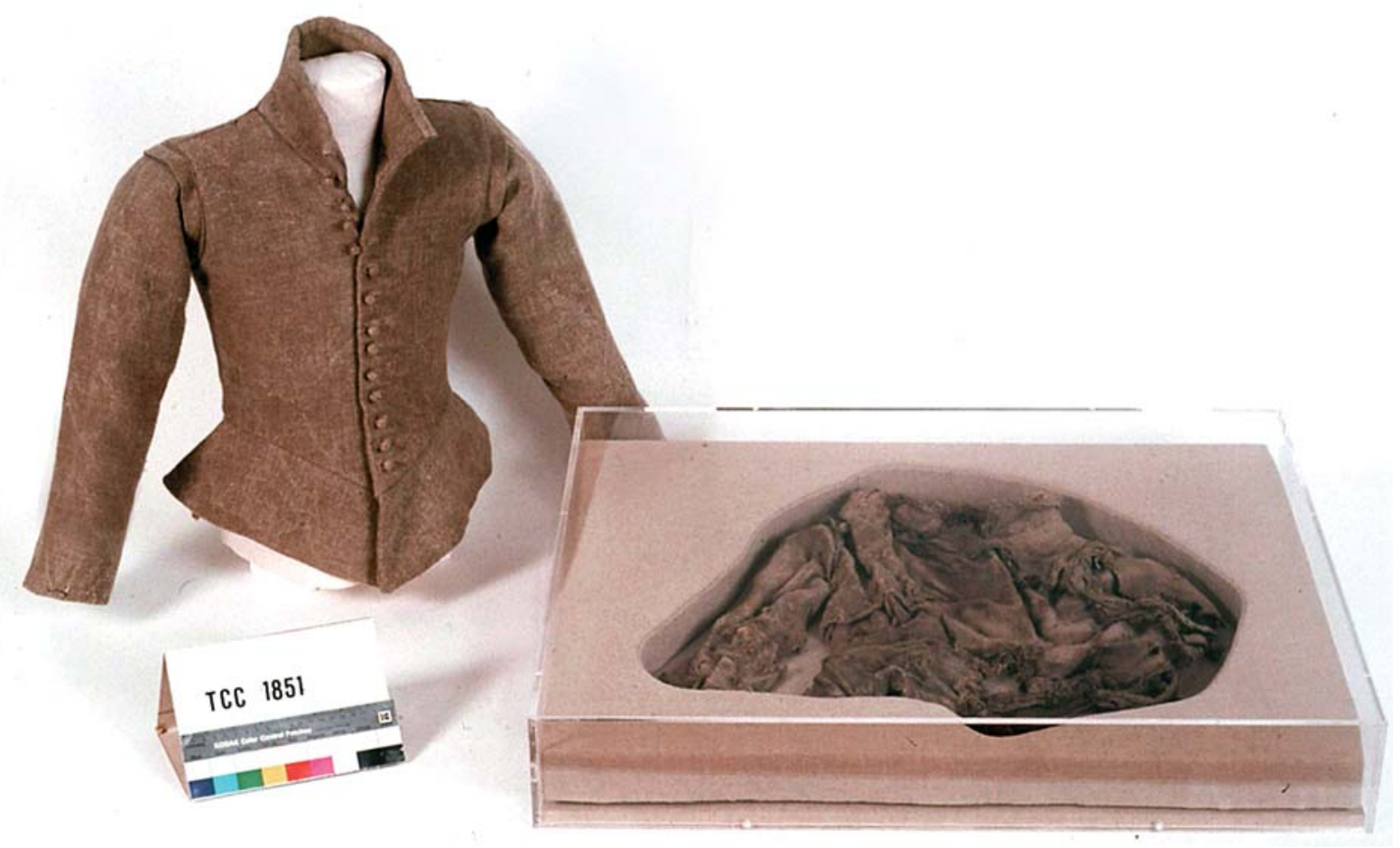

Figure 5 - The remains of a seventeenth century doublet, found in the Reigate Cache, in its storage-cum-display case and displayed alongside a modern replica (TCC 1851). 


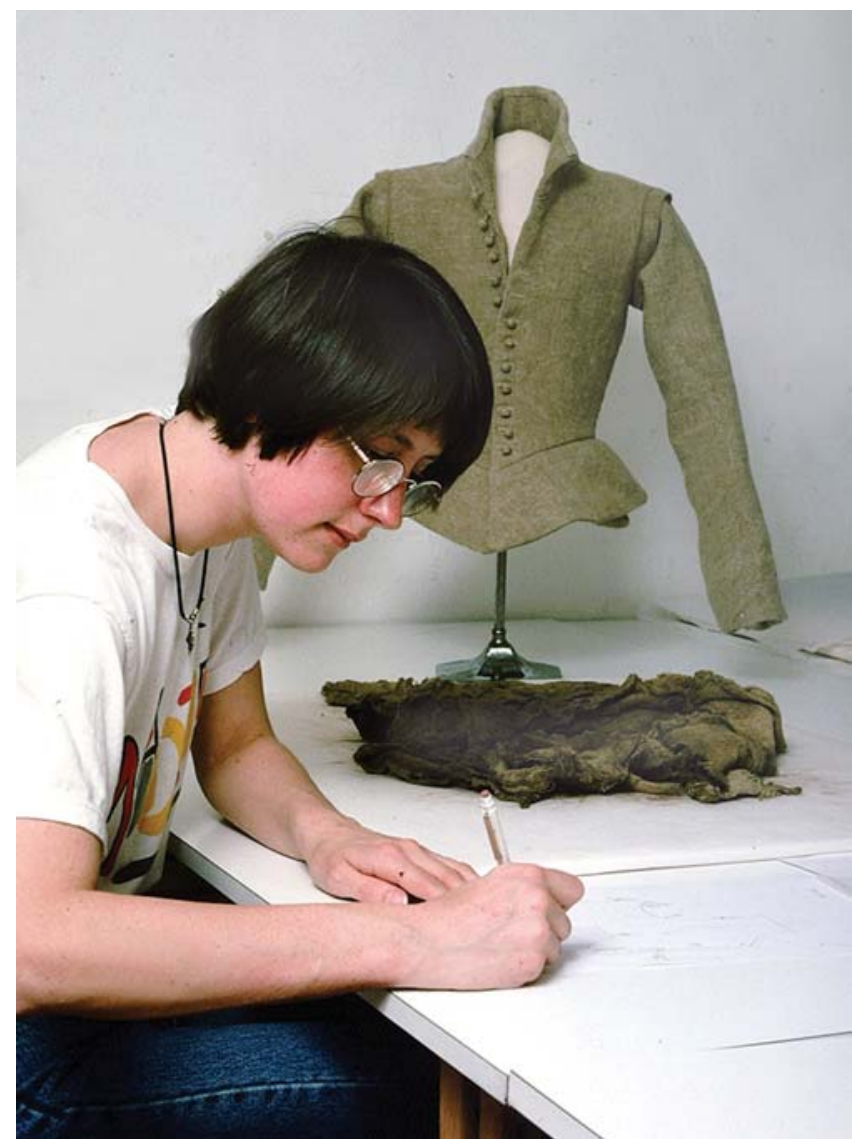

Figure 6 - Conservator Susan Stanton completing the documentation of the Reigate doublet; she made the replica doublet seen in the background (TCC 1851).

Cache finds as a preservation challenge

4. Cf. C. Schwartz personal communication (letter) to Charlotte Dew dated 26.6.05 (DCGP,Textile Conservation Centre, University of Southampton, UK).
The garments found within buildings are a preservation challenge due to the circumstances both of their concealment and their discovery. Caches are rarely uncovered in planned architectural or archaeological excavation, but are usually discovered during building work (repairs and maintenance) and sometimes during demolition work (Figures 7, 8 and 9). What is preserved (and how it is preserved) depends on what the cache finders, curators and conservators think is significant.

Finds may be viewed as rubbish (trash) and thrown away or destroyed. For example, a shoe and a 'corset type thing', found in building in Saltville, Virginia, USA, were burned by the house owner, 'thinking there was no significance to them't. In the case of a cache found in Cuckfield, Sussex, UK some items were lost between their discovery and taking them to the local museum. The boned 


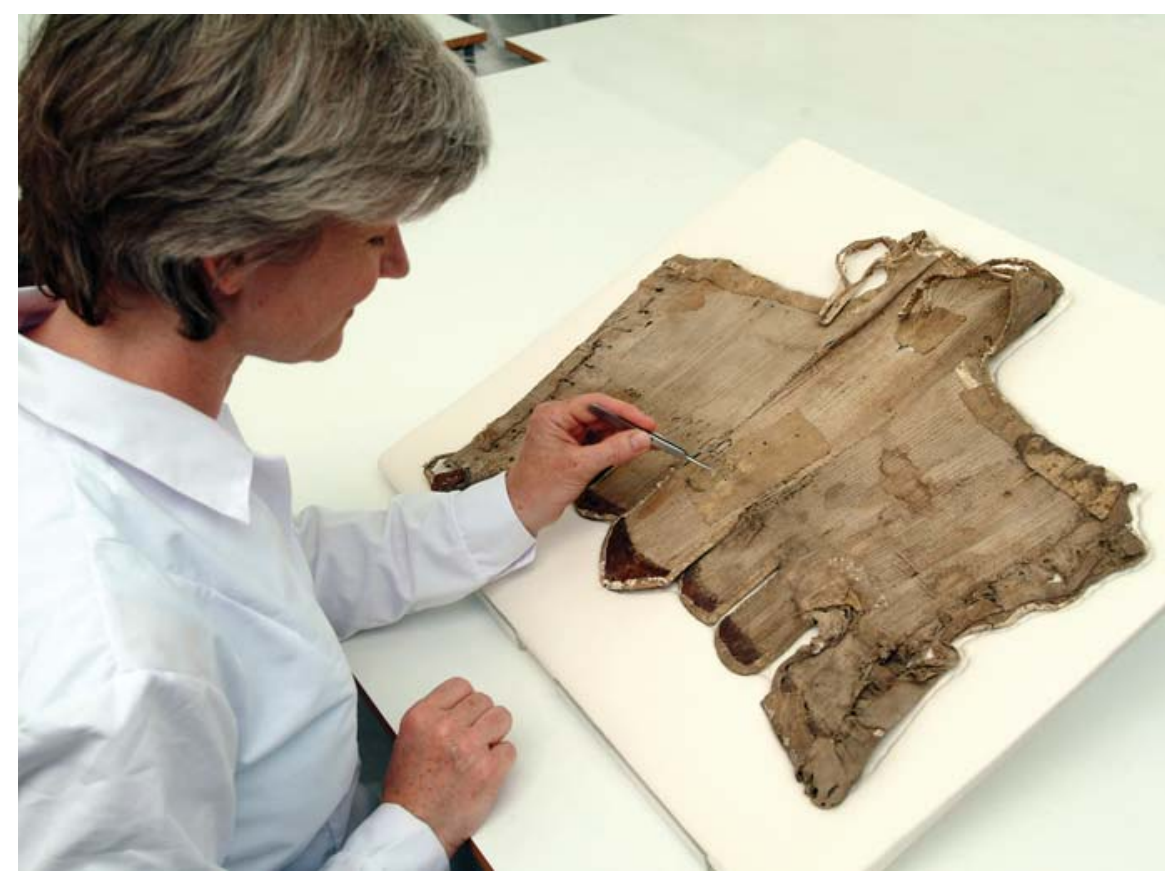

Figure 7 - Conservator Kathryn Gill with the early seventeenth century stays (corset) found in the Sittingbourne Cache.

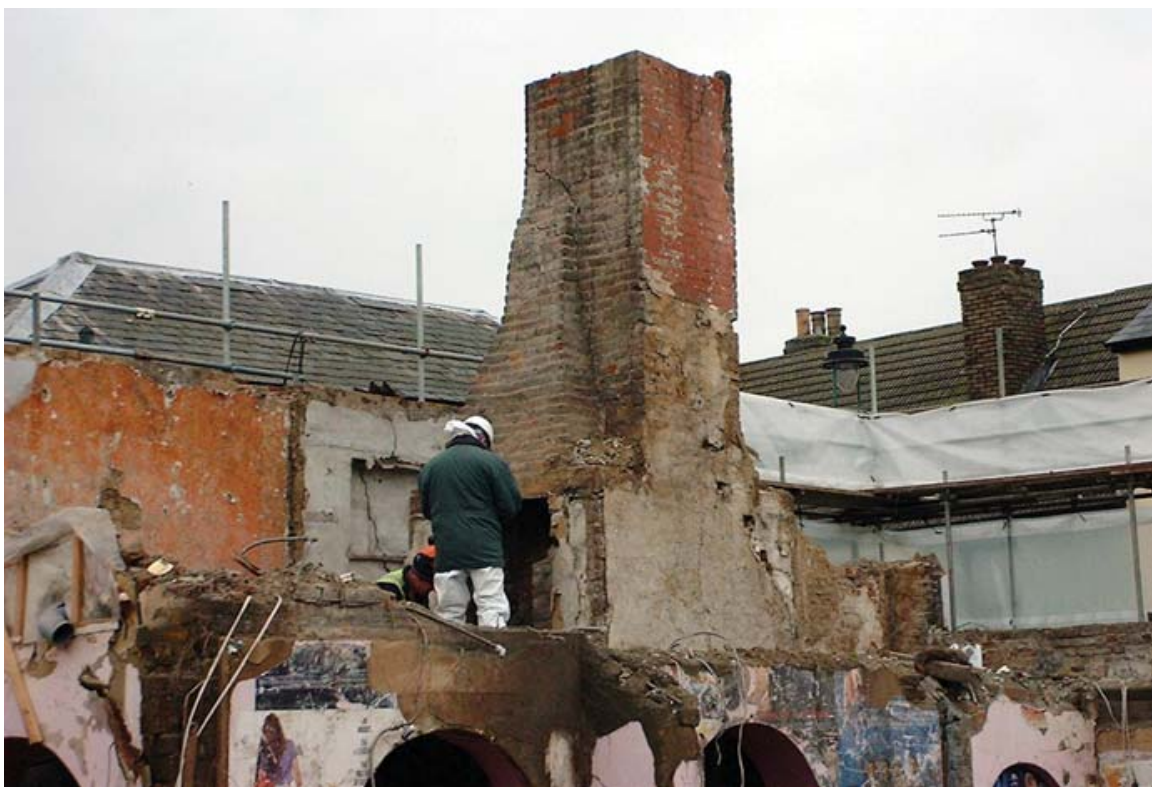

Figure 8 - Demolition of a fireplace and chimney; many items from the Sittingbourne Cache were found alongside the stepped, brick chimney flue. Photo credit: Alan Abbey and Phil Talbot. 


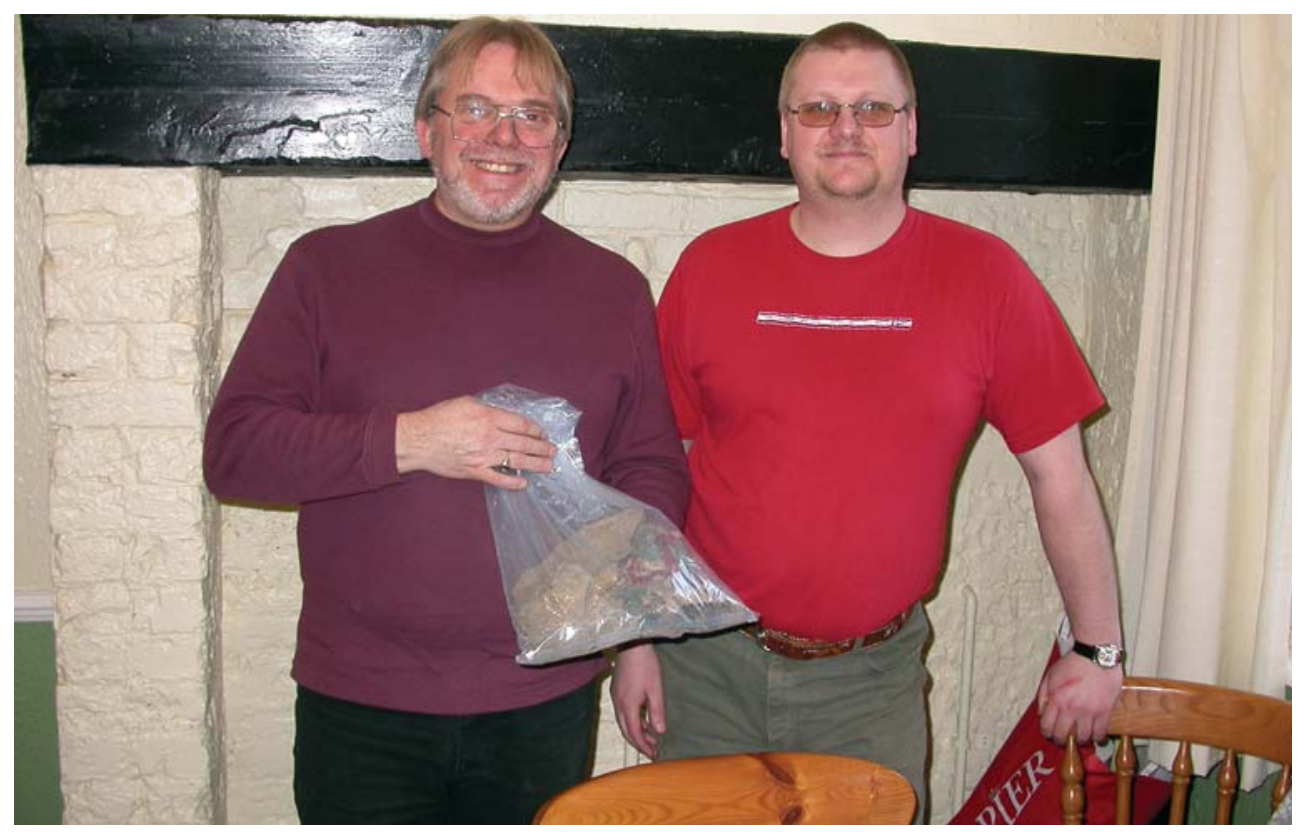

Figure 9 - Phil Talbot and Alan Abbey, members of the local history group which discovered the Sittingbourne Cache. Phil is holding a bag of small finds.

corset found with bottles, toys bricks, shoes and other garments, was considered too damaged to be of any interest and was thrown away. The Saltville and Cuckfield Caches demonstrate the vulnerability of caches to destruction (the burning of the corset-like thing) and to partial retention (keeping the shoes and toy bricks while throwing away the corset).

Partial documentation and retention of finds is characteristic, while the documentation and preservation of an entire cache remains unusual. Exceptions in the UK include the Nether Wallop Cache and the Brixham Cache, where the cache sites have been photographed, and the oral testimony of finders have been recorded, as well as details of the finds. In the case of the Brixham Cache, a local builder uncovered two caches while renovating a house in Devon, UK. They were found within the straw insulation placed behind the seventeenth century panelling of the house's cross passage. One cache, consisting of the fragmentary remains of a pair of seventeenth century breeches and a linen apron was found, tied together with straw, above the front door of the house. The other, found above the door leading from the cross passage into the main room, was a group of smaller items including an iron key, a barbed fish hook tied to string and an animal bone.

Selective retention and collection of finds appears to be more common. A builder who uncovers a mixed cache, and who collects old bottles, may retain the bottles found in the cache, but dispose of the other items in which he has no interest. Cache finds may be divided because of the acquisition policies of museums. For example, many boot and shoe finds have been reported and 
preserved in the UK because they were reported to the UK's national boot and shoe collection in Northampton (SWANN, 1969, 1996).

Some finds are attributed agency as protective agents. Some houseowners or finders view the found things as bringers of good luck, or the averters of bad luck, and will insist that the things are re-hidden (BROOKS, 2000). Some will make a substitution by replacing the removed item with something new: "We intend to replace the collection [three shoes plus other finds] with a modern one [shoe] before it [the cache] leaves the house. Just in case!" 5 .

The ethical and practical challenges of conserving garments which have been deliberately concealed in buildings provide a vivid means of showing how these textiles matter, both materially and symbolically. These differences are revealed in the way they are conserved, when conservation is viewed as a process of investigation, preservation and presentation (EASTOP, 2006b, 2006e). The following brief case studies demonstrate a range of treatment approaches and show that curatorial and conservation decisions have a big influence in how concealed garments are treated and exhibited (EASTOP, 2000).

Case studies

Each conservation intervention tends to prioritise one aspect for preservation (e.g. preserving evidence of the concealment itself, or preserving evidence of an object's use as a garment and as a concealment, or preserving evidence of the object as originally produced). The range of conservation interventions includes mounting for storage and display; minimal intervention and the making of replicas; and, more interventive treatments.

Detailed documentation and investigation of its materials and construction, coupled with mounting on a cloth-covered board, was the strategy adopted for the conservation of a stomacher la garment worn by women in the eighteenth centuryl found in the Nether Wallop Cache, Hampshire, UK. Detailed analysis showed that the stomacher had started 'life' as a corset, which had been cut down to make a stomacher. The stomacher had many signs of wear and repair which predated its concealment alongside a chimney flue built into the timberframed house. The decision was made to preserve all evidence of the stomacher's complex history of production and consumption. It underwent detailed examination and documentation but no interventive treatment (BARBIERI, 2003). X-radiography was used to document the internal structure and materials of the garment and confirmed that it was stiffened with strips of 'whalebone' (baleen) (BARBIERI, 2007). With the owner's consent, a sample of baleen was removed for DNA analysis, which showed that the baleen was from a North Atlantic right whale (Eubalaena glacialis), and from a previously unrecorded mitochondrial lineage of this species (EASTOP; McEWING, 2005) (Figures 10 and 11 ).

In the case of early seventeenth century linen doublet found in the Reigate Cache, the decision was made to preserve all evidence of use up to the
5.Personal communication, Frome, Somerset, UK, 1983 , recorded in the Concealed Shoe Index (Northampton Museums and Gardens, UK). 


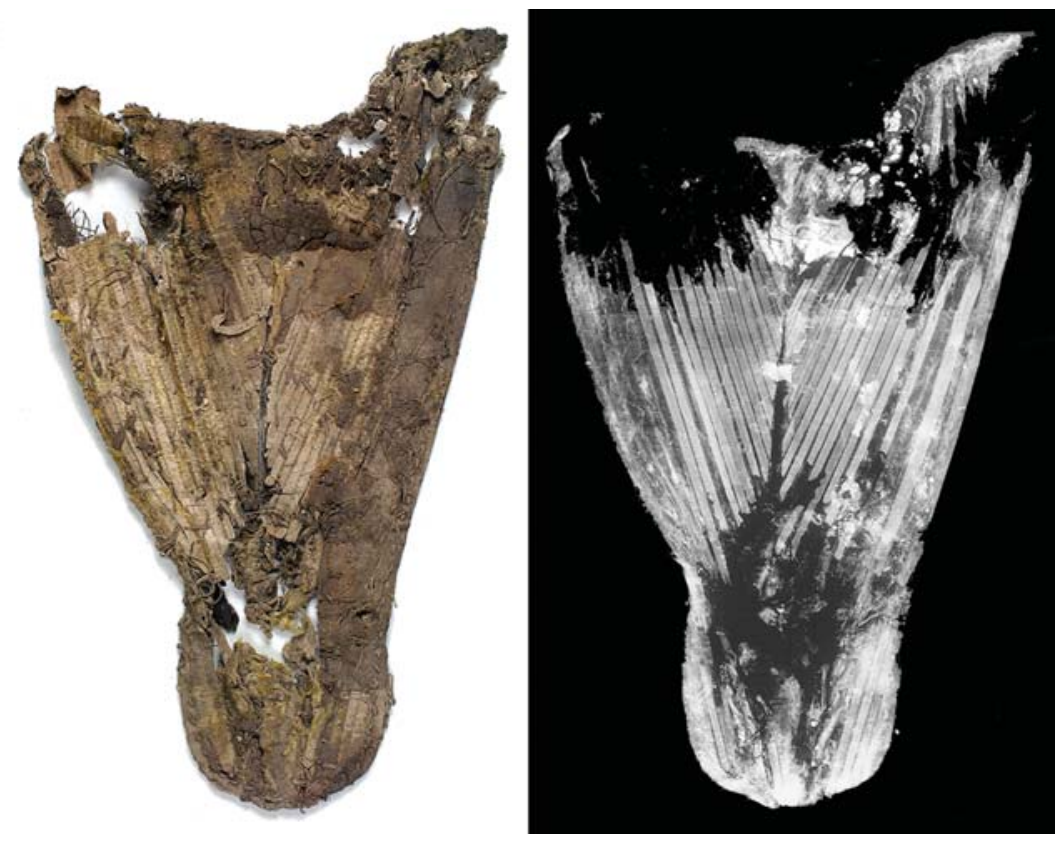

Figure 10 - The stomacher found in the Nether Wallop Cache, with an Xradiograph showing the strips of baleen ('whalebone').

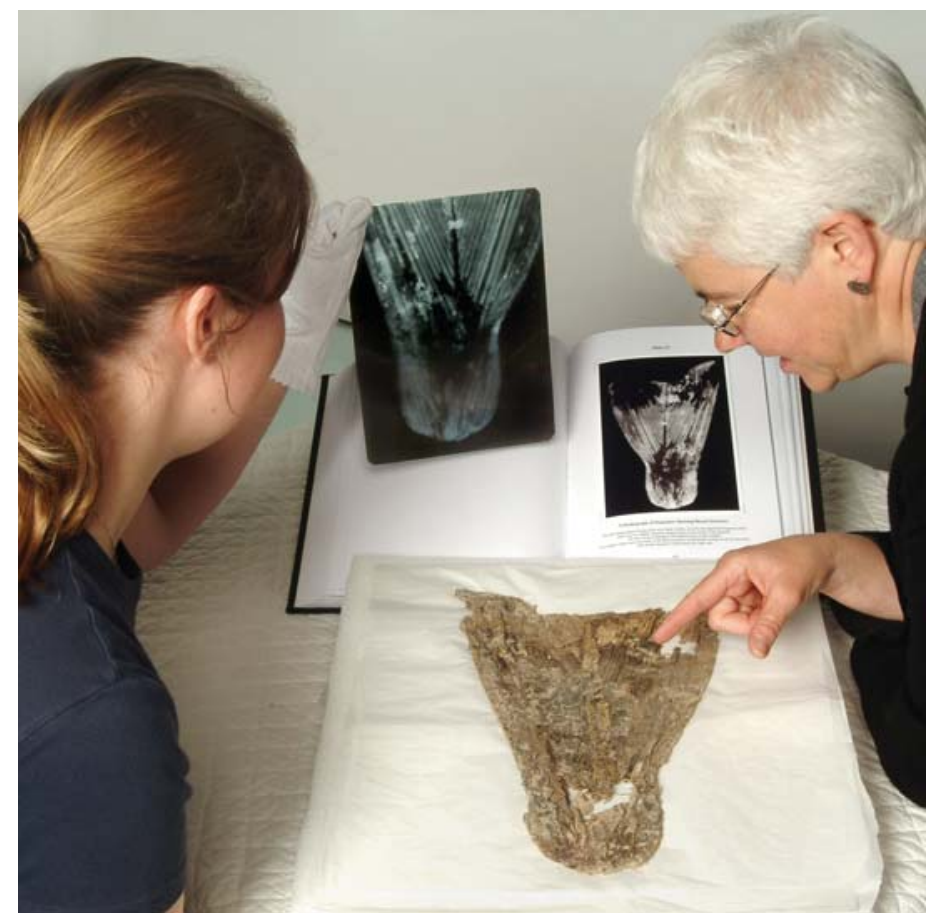

Figure 11 -Charlotte Dew and Dinah Eastop examining the Nether Wallop stomacher and its X-radiographs. 
point of discovery. In this case the evidence of the concealment context (e.g. its severe creasing) as well as the context of pre-concealment wear (e.g. signs of wear at the collar and underarms) was considered significant, and the cleaning of the Reigate doublet was restricted to the removal of post-discovery contaminants (STANTON, 1995; EASTOP, 2000, 2006g). No attempt was made to remove creasing or pre-discovery soiling. A replica doublet was made for display alongside the original to show how the fragmentary garment may have looked when new (Figures 5 and 6).

The conservation treatment selected for the tie-on pocket and the baby's cap found in a hop-filled wall cavity in Abingdon Cache 2 (noted above) prioritised the preservation of the artefacts' production and original appearance over evidence of their subsequent use as a concealment. Research showed the printed cloth pocket was a very rare example of a once very common type of cheap, tie-on pocket popular in the UK in the eighteenth century (Figure 2). It was therefore decided to implement a wet-cleaning treatment which would reduce the creases which distorted the shape of the pocket and put stress on the cloth. Wet-cleaning improved the appearance of the pocket by reducing creasing and soiling, making it much easier to see the original shape and form of the pocket. The crease reduction also made it easier to apply an effective stitched support to the weak, torn material. Thus the conservation treatment enabled the pocket to be displayed in such a way that it more closely resembled its 'as new' form. (HARRISON; GILL, 2002) Preserving evidence of its production was privileged over retaining evidence of its later use as part of a cache (Figures 3 and 4).

Extending the boundaries of conservation

The DCGP conservation strategy was not limited to the type of investigations and interventions noted above, or to preventive conservation measures (e.g. providing advice via the DCGP website). Raising public awareness of the practice of concealment and the historical significance of finds is an important part of the DCGP because ignorance of caches can contribute to their loss and damage. Various 'outreach' measures were taken to provoke public interest in and understanding of cache finds, including the preparation of articles in both specialist publications and the popular press (e.g. local newspapers), and establishing a website, and organising a touring exhibition.

An oral history programme was initiated as part of the DCGP to learn more about the circumstances of discovery and concealment, and more about the views of finders, custodians and conservators. Sound recordings relating to the following UK caches have been made: the Brixham Cache (EASTOP; DEW, 2006); the Nether Wallop Cache; the Reigate Cache, the Sittingbourne Cache (EASTOP, 2007) (Figure 9). The recordings are held by the Wessex Film and Sound Archive, Winchester, UK, where they are publicly accessible. 
Caches often remain in the custodianship of the finder or the owner of the building in which they were found. It can be difficult to obtain a clear picture of when and where caches have been found because museums may not collect an entire cache, choosing instead to retain parts considered significant for their collections. A database of caches was therefore established as part of the DCGP; it can be accessed via the project website: <www.concealedgarments.org>.

The database brings together information about caches in the UK and create a 'virtual collection' of UK finds. The data base also includes objects that are no longer accessible, either because they have been destroyed or because they have been re-concealed. Objects are documented individually and are grouped by cache. The virtual collection enables the number of particular object types to be determined, as well as the frequency with which objects are discovered in particular locations. Finders, owners and museum staff are encouraged to report finds via the on-line 'Report a Find' forms available on the site (Figure 12). The site has been successful in attracting enquiries and information about caches from buildings in the UK, Sweden, North America and Australia. The website also contains an extensive bibliography and advice for finders about what to do when they discover a cache.

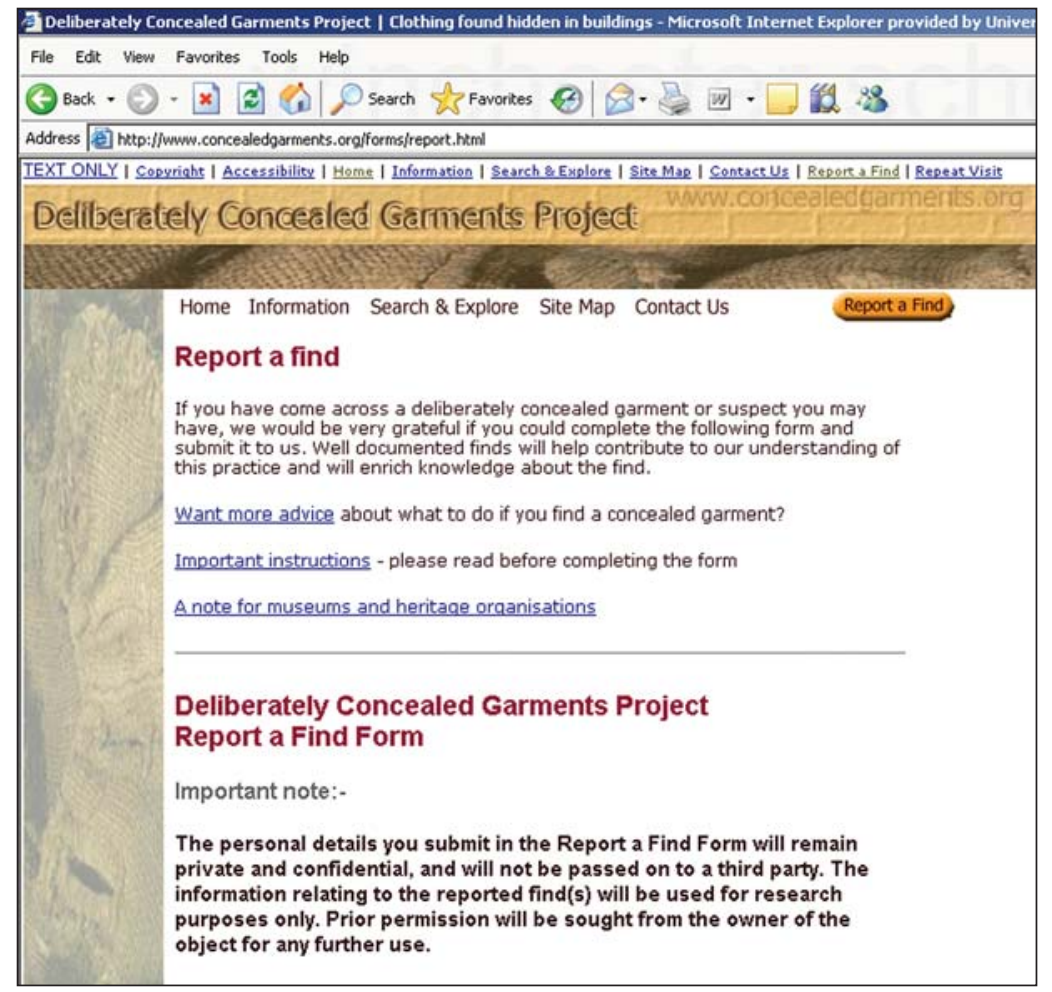

Figure 12 - The 'Report a Find' page of the DCGP website. 
Part of the DCGP's conservation strategy was the development of a touring exhibition, called Hidden House History. The exhibition displayed finds and explored the practice of concealment. Visitors were invited to report finds and to consider the ethical questions raised by these finds, e.g. they were asked for their views on what should happen to caches after they have been discovered. Hidden House History exhibited once-concealed objects in a variety of ways. Three caches were displayed in reconstructions of the locations in which they were found: under floorboards (Figure 13); alongside a chimney flue; and, within a lath and plaster wall. The reconstructions were designed so that the finds could be safely displayed while at the same time evoking the sense of discovering objects hidden in dark, cramped conditions.

Finds from four other UK caches were displayed in traditional museum cases (Figure 2). Fragmentary, soiled and creased garments were displayed to show that even the most damaged finds can be of considerable historic interest and are therefore worth preserving. For example, the damaged stomacher from the Nether Wallop Cache was displayed alongside the results of the DNA analysis of its baleen stiffening which led to the identification of a previously unknown lineage of North Atlantic right whale, as outlined above. This demonstrates that

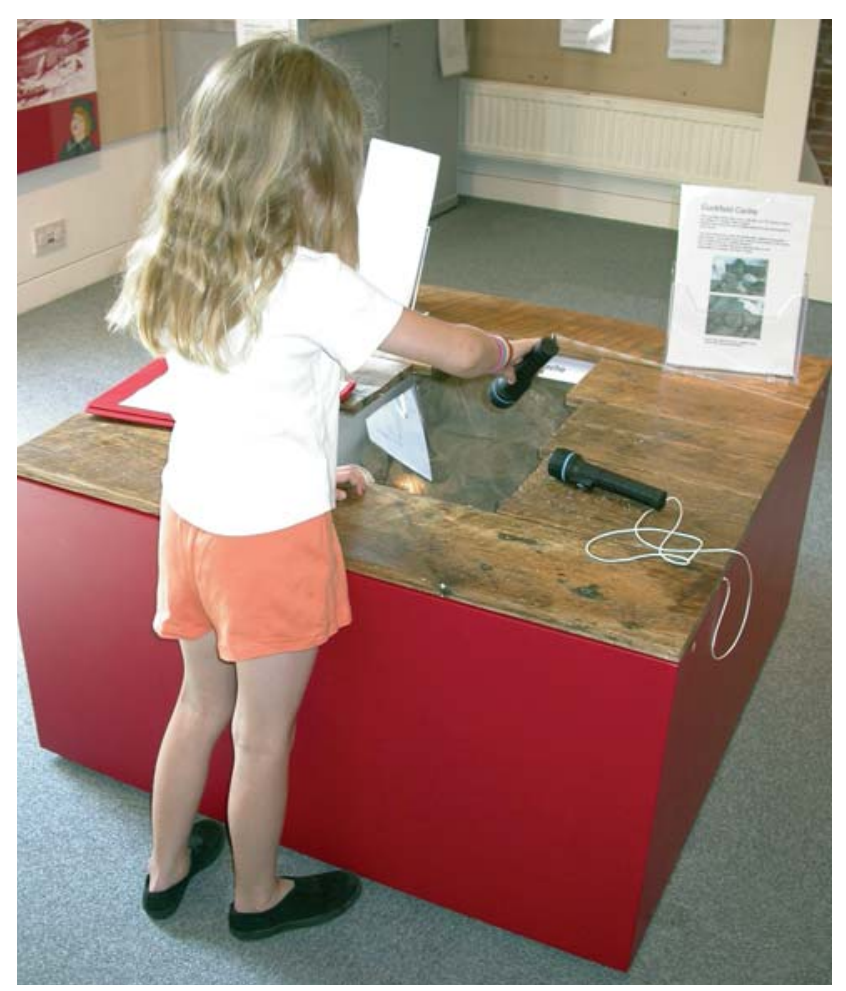

Figure 13 - A young museum visitor uses a torch to examine the Cuckfield Cache, which was displayed in the Hidden House History exhibition in a case which replicated the cache site (under floorboards). 
even a very damaged and apparently worthless garment can be a valuable source of both historical and natural history information (Figures 10 and 11 ).

A similar approach was adopted for the preservation and display of the remains of a very rare early seventeenth century doublet, found in Abingdon Cache 1. The fragmentary garment was displayed alongside a life-size replica (Figure 2). Dye analysis revealed the presence of indigotin in the wool outer fabric, which suggests that the original colour of the wool outer fabric /which is now brown) was probably blue. The replica was therefore made with blue wool, which created a dramatic contrast between old and new and encouraged visitors to think differently about the fragmentary, discoloured doublet.

Discussion

Materials and objects are modified by human action, and human action uses objects. Garments deliberately concealed within buildings, and the conservation challenges they pose, provide a vivid model of material culture in action because their discovery and subsequent treatment draws attention to the evolving dialectic over time between their material properties and their social properties. The former result from the materials they are made from, the way they are made, the way they have changed over time, e.g. through wear and tear, repairs and other alterations. Social properties include how they have been used, e.g. as garments, as concealments within buildings, and as museum exhibits.

Most garments found in caches bear signs of use. This may be in the form of creases and abrasions from wear (e.g. the collar of the Reigate doublet was creased from wear) and alterations (e.g. the Nether Wallop stomacher has material evidence that is has been re-covered). When a garment is selected for concealment it enters a new phase of use, connected with a building and probably with beliefs about the perceived risk to buildings and beliefs about averting such risks. The discovery of a cache involves yet another set of social relations, e.g. between the current owner or custodian of the building and the finders of the cache. In some instances, the search for information and advice about the cache will widen the social network to include local historians, museum curators and conservators. The interplay between object and social life evolves over time, and changes in material properties are the outcome of the cumulative effect of social action over time.

At each phase there is an interaction between the material properties of the object and social action (what people do with the object and how they explain their actions). Each subsequent phase inherits the object from the previous phase. In the case of the Nether Wallop stomacher, the flax plant for the linen had to be grown and the whale had to grow. The flax was harvested and the whale was hunted; the linen yarn and the baleen strips were processed and used to make a garment (probably a corset); the corset was used as a garment and altered by being cut down to make a stomacher, which was later repaired and 
given an new cloth covering. The heavily worn garment was then selected for inclusion in a cache placed in a timber-framed house in Nether Wallop and was hidden alongside a newly installed chimney flue. Many years later, during the restoration of the house, the cache was uncovered, and retained by the houseowners because of its historic interest for them. They sought the advice of curators and conservators, with the result that baleen from the stomacher underwent DNA analysis and the stomacher was later exhibited.

Once on display, the garments enter another social sphere, where their changing material and symbolic properties may have to be explained and illustrated. For example, the recent exhibition of the Nether Wallop stomacher focused on its significance as material proof of a decline in the biodiversity of a certain type of whale. In the case of the Abingdon doublet, it was exhibited as a rare example of everyday boy's wear of seventeenth century, northern Europe.

When a garment found in a cache is brought for conservation treatment, the condition of its materials and structure will be evaluated, and considered in the light of its current role as an exhibit or study item. The conservators and curators have to decide which aspects of its material-cum-symbolic properties should be preserved and how this should be achieved. For example, the decision to restrict the conservation of the Nether Wallop stomacher to detailed documentation and material analysis, or the decision to retain creases (as in the Reigate doublet) or remove them (as in the Abingdon tie-on pocket). Conservation decisions are part of social action, and will have effects on the material as well as future social roles of the objects.

Each decision has the effect of privileging preservation of evidence of one aspect over another (EASTOP, 1998, 2001); this is not unique to garments discovered hidden within buildings. Orlofsky and Trupin (1994) have demonstrated the role of connoiseurship on the conservation of textiles. Understanding the needs of different users has resulted in recent changes in conservation practice (CLAVIR, 1994, 2006). Some of the most impressive examples of community involvement in conservation have been reported from South America, notably at the Museum Forum held at the international meeting of the Conservation Committee of ICOM in Rio de Janeiro in 2002 (EASTOP, 2003). Another interesting example is collaborative project to conserve Peruvian khipu (PETERS, 2006).

\section{Conclusion}

The DCGP demonstrates the complex relationship between people, things and language, and the influential role of textile conservation in preserving and presenting certain views of objects. This paper argues that an understanding of 'material culture' can help to identify and clarify the practical and ethical dilemmas of curating and conserving textiles. Cache finds provide excellent models of 'material culture' in action because they highlight how the categorization of finds affects whether they are preserved and collected. It also shows how 
significance assessment affects what is preserved and how it is preserved. The benefits of cross-sector working, e.g. public consultation, public engagement, working with builders are also made clear. The DCGP has benefited greatly from cross-sector working, e.g. inter-University research collaboration, and co-working with local archives and museums.

The DCGP has shown that a 'material culture' approach has three main benefits. First, it facilitates integrated thinking about the physical properties of objects and their social use. Second, it makes clear that 'true nature' of objects varies and it culturally determined, as shown by the variety of responses to the discovery of garments concealed within buildings. Third, a material culture approach has facilitated discussion of options for the investigation, preservation and presentation of once-concealed garments.

\section{REFERENCES}

APPADURAI,A. (Ed.) The social life of things. Cambridge: Cambridge University Press, 1986.

BARBIERI, G. Memoirs of an 18th century stomacher: A strategy for documenting the multiple object biographies of a once-concealed garment. Southampton: University of Southampton, UK, 2003 (Unpublished MA dissertation).

BARBIERI, G. Investigation of the Nether Wallop stomacher. In: O'CONNOR, S.; BROOKS, M. M. (Eds.). X-Radiography of Textiles, Dress and Related Objects. Oxford: Elsevier, 2007 (in press).

BROOKS, E. Watch your step; a tale of 'builders'sacrifice' and lost soles. The National Trust Magazine, London, UK, v. 91, p. 67-68, 2000.

CLAVIR, M. Preserving conceptual integrity: ethics and theory in preventive conservation. In: ROY,A.; SMITH, P. (Eds). Preventive conservation practice, theory and research. London: IIC, 1994, p. 53-57.

CLAVIR, M. Preserving what is valued: museums, conservation and first nations. Vancouver: University of British Colombia Press, 2002.

EASTOP, D. Decision-making in conservation: determining the role of artefacts. In:TÍMÁR-BALÁZSY, Á.; EASTOP, D.(Eds). International Perspectives:Textile Conservation 1995-98. London:Archetype, 1998, p. 43-46.

Iban Ikats: people, objects and metaphors. London:Anthropology Department, University College London, 1998 (Unpublished MA dissertation).

Textiles as multiple and competing histories. In: BROOKS, M. M. (Ed.). Textiles revealed. Object lessons in historic textiles and costume research. London:Archetype, 2000, p. 17-28.

Garments deliberately concealed in buildings. In: WALLIS, R.; LYMER, K. (Eds). $A$ permeability of boundaries? New approaches to the archaeology of Art, Religion and Folklore. Oxford: British Archaeological Reports, 2001. p. 79-83 (BAR International Series S936). 
Conservation as a democratizing practice: learning from Latin America. ICOM UK News, n. 63, p. 22-24, Dec. 2002.

Dilemas da preservação: aprendendo com o filme Toy Story 2. In: De PAULA, C.T. (Ed.). Tecidos e sua conservação no Brasil: museus e colleções [Textile conservation in Brazil: museums and collections]. Preprints of the international seminar arranged by the Museu Paulista of USP, 8-13 May 2006. São Paulo: Museu Paulista da Universidade de São Paulo, 2006a. p. 17-23.

A conservação de têxteis como uma práctica de conservação, de investigação e de apresentação. In: De PAULA, C.T. (Ed.). Tecidos e sua conservação no Brasil: museus e colleções [Textile conservation in Brazil: museums and collections]. Preprints of the international seminar arranged by the Museu Paulista of USP, 8-13 May 2006. São Paulo: Museu Paulista da Universidade de São Paulo, 2006, p. 52-58.

A conservação de têxteis como cultura material. In: De PAULA, C.T. (Ed.). Tecidos e sua conservação no Brasil: museus e colleções [Textile conservation in Brazil: museums and collections]. Preprints of the international seminar arranged by the Museu Paulista of USP, 8-13 May 2006. São Paulo: Museu Paulista da Universidade de São Paulo, 2006c, p. 121-122.

Preservation dilemmas: learning from Toy Story 2. In: De PAULA, C.T. (Ed.). Tecidos e sua conservação no Brasil: museus e colleções [Textile conservation in Brazil: museums and collections]. Preprints of the international seminar arranged by the Museu Paulista of USP, 8-13 May 2006. São Paulo: Museu Paulista da Universidade de São Paulo, 2006d, p. 203-209.

In: De PAULA, C.T.(Ed.). Tecidos e sua conservação no Brasil: museus e colleções [Textile conservation in Brazil: museums and collections]. Preprints of the international seminar arranged by the Museu Paulista of USP, 8-13 May 2006. São Paulo: Museu Paulista da Universidade de São Paulo, 2006e, p. 238-244.

Textile conservation as material culture. In:De PAULA, C.T.(Ed.). Tecidos e sua conservação no Brasil: museus e colleções [Textile conservation in Brazil:museums and collections]. Preprints of the international seminar arranged by the Museu Paulista of USP, 8-13 May 2006. São Paulo: Museu Paulista da Universidade de São Paulo, 2006f, p. 307-308.

Conservation as Material Culture. In:TILLEY, C.; KEANE, W.; KÜCHLER, S.; ROWLANDS, M.; SPYER, P. (Eds.). Handbook of Material Culture. London: Sage, 2006g. p. 516-533.

Outside In: Making Sense of the Deliberate Concealment of Garments within Buildings. Textile. The Journal of Cloth and Culture, London, UK, v. 4, n. 3, p. 238-255, $2006 \mathrm{~h}$.

Conservation as social and material. Intervention column. Icon News. The Magazine of the [UK] Institute for Conservation, London, UK, n. 5, p. 56, July $2006 \mathrm{i}$.

Sound recording and text creation: oral history and the Deliberately Concealed Garments Project. In: KRAMER, E.;HAYWARD, M. (Eds.) Textiles and text. London:Archetype, 2007 (in press).

EASTOP,D.;DEW, C. Secret agents: deliberately concealed garments as symbolic textiles. In:VUORI, J. (Ed.). Tales in the textile. The conservation of flags and other symbolic textiles. Preprints of the North American Textile Conservation Conference 2003. Albany, NY: NATCC, 2003. p. 5-15. 
Context and Meaning generation: the conservation of garments deliberately concealed in buildings. In: SAUNDERS, D., TOWNSEND, J.H.; WOODCOCK, S. (Eds.). The object in context: crossing conservation boundaries. Preprints of the 2006 Congress of IIC. Munich: IIC, 2006, p. 17-22.

EASTOP, D.; McEWING, R. Informing textile and wildlife conservation: DNA analysis of baleen from an eighteenth century garment found deliberately concealed in a building. In: JANAWAY, R.; WYETH, P. (Eds.). Scientific analysis of ancient and bistoric textiles: informing preservation, display and interpretation. London:Archetype, 2005. p. 161-167.

EASTON,T. Spiritual Middens. In: Oliver, P. (Ed.). Encyclopaedia of Vernacular Architecture of the World. v. I. Cambridge: Cambridge University Press, 1995. p. 568.

HANSEN, K. T. Salaula: the world if secondhand clothing and Zambia. Chicago: University of Chicago Press, 2000.

HARRISON,A.; GILL, K.An eighteenth-century detachable pocket and baby's cap, found concealed in a wall cavity: conservation and research. Textile History, v. 33, n. 2, p. 177-194, 2002

MERRIFIELD, R.. The archaeology of ritual and magic. Batsford, London, 1987.

ORLOFSKY, P.;TRUPIN, D. The role of connoiseurship in determining the textile conservator's treatment options.Journal of the American Institute for Conservation, v. 32, p. 109-118, 1993.

PETERS, R. For use and study: a collaborative project to conserve Peruvian khipu. Icon News, the Magazine of the [UK] Institute of Conservation, London, UK, v. 4, p. 54, May 2006.

STANTON, S. A seventeenth-century linen doublet: the development of a strategy for the documentation, preservation and display of a rare item of working class dress. London, UK,: Courtauld Institute of Art-Textile Conservation Centre, 1995 (unpublished post-graduate diploma report).

SWANN, J. Shoes concealed in buildings. Northampton County Borough Museums and Art Gallery Journal, v. 6, p. 8-21, Dec. 1969.

SWANN, J. Shoes concealed in buildings. Costume: The Journal of the [UK]Costume Society, v. 30, p. 56-69, 1996.

TILLEY, C.; KEANE, W.; KÜCHLER, S.; ROWLANDS, M.; SPYER, P. (Eds.). Handbook of Material Culture. London: Sage, 2006.

Artigo apresentado em 2/2007. Aprovado em 4/2007. 